\title{
Evaluasi Kinerja Aparatur Sipil Negara Dinas Kearsipan Dan Perpustakaan Kota Kediri
}

\author{
Siti Zulaikah \\ Dinas Kearsipan dan Perpustakaan Kota Kediri \\ Email: zulaikah.siti@gmail.com
}

\begin{abstract}
ABSTRAK
Stigma yang berkembang bahwa ASN yang ditempatkan pada Dinas Kearsipan dan Perpustakaan adalah ASN yang terbuang atau "diarsipkan". Hal ini menarik minat peneliti untuk melakukan penelitian dengan tujuan untuk mendeskripsikan dan mengevaluasi kinerja pegawai pada Dinas Kearsipan dan Perpustakaan Kota Kediri serta untuk mengetahui faktor yang mendukung dan menghambat kinerja di Dinas Kearsipan dan Perpustakaan Kota Kediri. Untuk menjawab tujuan penelitian diukur melalui Orientasi Pelayanan, Integritas, Komitmen, Kedisiplinan, Kerjasama, dan Kepemimpinan.

Penelitian ini berjenis deskriptif kualitatif, dengan lokasi penelitian pada Dinas Kearsipan dan Perpustakaan Kota Kediri. Data berasal dari wawancara dengan 22 orang informan dan juga dari pengamatan langsung di lokasi penelitian. Sedangkan data sekunder berasal dari data dan dokumen yang dimiliki oleh instansi. Penarikan kesimpulan berdasarkan data yang diolah dengan menggunakan analisis model interaktif.

Hasil penelitian menunjukkan bahwa kinerja pada Dinas Kearsipan dan Perpustakaan Kota Kediri sudah baik, namun masih sangat perlu dioptimakan. Hal ini terlihat dari kerjasama, kedisiplinan dan kepemimpinan yang masih harus ditingkatkan.Sedangkan dari segi pelayanan, integritas, dan komitmen sudah baik.

Adapun faktor pendukung kinerja ASN diantaranya adanya semangat/motivasi diri yang kuat untuk melaksanakan pekerjaan dengan penuh tanggung jawab, berintegritas dan penuh komitmen, adanya reward TPP dari Pemerintah Kota Kediri dan lingkungan kerja yang kondusif. Sedangkan faktor penghambat kinerjanya diantaranya kurangnya sumber daya manusia, kurangnya sarana dan prasarana, dankurangnya alokasi anggaran untuk dinas dan anggaran peningkatan kompetensi pegawai.
\end{abstract}

Kata kunci: kinerja, orientasi pelayanan, integritas, komitmen, kedisiplinan, kerjasama, kepemimpinan.

\section{Evaluation of Civil Servants Performance in the Archives and Library Office of Kediri Municipality}

\footnotetext{
Abstrack

The Stigmain Civil Servants (ASN) who are assigned in the Archives and Library office of Kediri Municipality is that they think that they are archived or to be plaeed in the wrong place. This stigma makes the researcher interested in order to describe and evaluate the performance of Anchives and Library employeeand also to makeus knowthe supported factor and the inbibitor factor of performance in Archives and Library Office in the Kediri Municipality Answering the goal of this research is measured by Service Oriented, Integrity, Commitment, Discipline, Cooperation, and Leadership.

This research is classified as the qualitative descriptive, the location of the research is the Archives and Library Office in Kediri Municipality. Interviewing 22 persons and direct research in the location. The Secunder data comes from the data and document of this office. The conclusion based on processed data by using analyze of interactive model.

Result of the research is the performance of this office generally is good, but need tobe optimalized. It can be know from the cooperation, discipline, and leadership need to be optimalized. But the serviceoriented, integrity and mommitment already good enough

The supported factor for the performances of civil servants ( ASN) are the self motivated to do the work responbility, integrity and full of commitment. The Rewand from Goverment and the condusive working
} 
environment. The unsupported factor are the Lack of human resources, measured infrastructure, lack of the allocation of the budget for the office and for the enhance employee competent.

Key words = Performance, Service Oriented, Integrity, Commitment, Discipline, Cooperation, Leadership.'

\section{PENDAHULUAN}

Kinerja atau prestasi kerja (performance) dapat diartikan sebagai pencapaian hasil kerja sesuai dengan aturan dan standar yang berlaku pada masingmasing organisasi. Kinerja pegawai yang baik secara langsung akan mempengaruhi kinerja organisasinya, kondisi tersebut berdampak salah satunya perubahan tingkat kepercayaan masyarakat terhadap birokrasi. Untuk itu memberikan kinerja yang maksimal sangat penting, karena selain merubah image buruk birokrasi, perbaikan kinerja juga dapat memajukan organisasi yang terkait.

Terbitnya Peraturan Pemerintah Nomor 18 Tahun 2016 tentang Perangkat Daerah menggantikan Peraturan Pemerintah Nomor 41 Tahun 2007 tentang Organisasi Perangkat Daerah telah merubah struktur organisasi di Dinas Kearsipan dan Perpustakaan Kota Kediri sejak akhir tahun 2016. Tujuan dikeluarkannya peraturan ini adalah agar terbentuk organisasi perangkat daerah yang tepat fungsi dan sesuai dengan ukuran.

Peraturan Pemerintah Nomor 18 Tahun 2016 ini memberikan arah dan pedoman yang jelas kepada daerah dalam menata perangkat daerah secara efisien, efektif, dan rasional sesuai dengan kebutuhan nyata dan kemampuan daerah masing-masing serta adanya koordinasi, integrasi, sinkronisasi dan simplifikasi serta komunikasi kelembagaan antara pusat dan daerah.

Pegawai Dinas Kearsipan dan Perpustakaan Kota Kediri sebagai salah satu unsur utama SDM aparatur negara mempunyai peranan penting yang menentukan baik buruknya ASN di Kota Kediri. Selain menegakkan disiplin, dan memberikan contoh yang baik, juga harus mampu memainkan peran sebagai pegawai yang mempunyai kompetensi yang diindikasikan dari sikap dan perilakunya yang penuh dengan kesetiaan dan ketaatan kepada Negara, bermoral dan bermental baik, profesional, sadar akan tanggung jawabnya sebagai pelayanan publik, serta mampu menjadi perekat persatuan dan kesatuan bangsa.
Sebagai organisasi pelayan bagi masyarakat, organisasi masyarakat, instansi Pemerintah Kota Kediri lainnya dan instansi di luar Pemerintah Kota Kediri, maka Dinas Kearsipan dan Perpustakaan Kota Kediri diharapkan memiliki sumber daya manusia aparatur yang memadai dari segi kuantitas maupun kualitas yang dijiwai budaya organisasinya melalui pengukuran kinerja pegawainya.

Namun pentingnya peranan ASN Dinas Kearsipan dan PerpustakaanKota Kediri dari segi pelayanan berbanding terbalik dengan stigma buruk yang beredar bahwa ASN yang yang ditempatkan di dinas kearsipan dan perpustakaan adalah ASN terbuang atau "diarsipkan". Stigma tersebut tidak hanya dilekatkan oleh orang di luar dinas kearsipan dan perpustakaan bahkan ASNnya sendiri banyak yang merasa tidak berharga, terbuang dan disisihkan, walaupun tidak seluruhnya. Ini mengakibatkan kinerja ASN di Dinas Kearsipan dan PerpustakaanKota Kediri tidak optimal Berdasarkan uraian di atas, maka penulis tertarik untuk mengadakanpenelitian dengan judul Evaluasi Kinerja Aparatur Sipil Negara Di Dinas Kearsipan dan Perpustakaan Kota Kediri.

\section{Fokus Penelitian}

Fokus penelitian adalah :

1. Orientasi Pelayanan pada Di Dinas Kearsipan dan Perpustakaan Kota Kediri;

2. Integritas Aparatur pada Di Dinas Kearsipan dan Perpustakaan Kota Kediri;

3. Komitmen PNS pada Di Dinas Kearsipan dan Perpustakaan Kota Kediri;

4. Kedisiplinan PNS pada Di Dinas Kearsipan dan Perpustakaan Kota Kediri;

5. Kerjasama antar pegawai pada Di Dinas Kearsipan dan Perpustakaan Kota Kediri; 
6. Gaya Kepemimpinan pejabat menurut PNS pada Di Dinas Kearsipan dan Perpustakaan Kota Kediri.

\section{Tujuan Penelitian}

Untuk memperoleh pemahaman tentang kinerja Aparatur Sipil Negara (ASN) di Dinas Kearsipan dan Perpustakaan Kota Kediri;

Untuk memahami faktor-faktor pendukung dan penghambat kinerja Aparatur Sipil Negara (ASN) pada Dinas Kearsipan dan Perpustakaan Kota Kediri.

\section{Manfaat Penelitian}

Berdasarkan kegunaan teoritis. Diharapkan memberi kontribusi positifterhadap pengembangan ilmu pengetahuan khususnya mengenai kinerja ASN di lingkupDinas Kearsipan dan Perpustakaan Kota Kediri.

Berdasarkan kegunaan praktis.

Diharapkan hasil penelitian dapat menjadibahan pertimbangan dan perbandingan bagi pembuat kebijakan dalam menjalankan tugasnya terutama dalam meningkatkan kinerja ASN di tubuh Dinas Kearsipan dan Perpustakaan Kota Kediri.

\section{Landasan Teori \\ Pengertian Kinerja}

Berdasarkan kamus The New Webster Dictionary istilah Kinerja atau prestasi sebenarnya pengalih bahasaan dari bahasa Inggris"performance".

Kinerja atau prestasi kerja (performance) dapat diartikan sebagai pencapaian hasil kerja sesuai dengan aturan dan standar yang berlaku pada masingmasing organisasi. Simamora (2000) menyatakan bahwa kinerja merupakan suatu persyaratan-persyaratan tertentu yang akhirnya secara langsung dapat tercermin dari output yang dihasilkan baik yang berupa jumlah maupun kualitasnya. Output yang dihasilkan menurut Simamora dapat berupa fisik maupun nonfisik yang menyebutnya berupa karya, yaitu suatu hasil/pekerjaan baik berupa fisik/material maupun nonfisik maupun nonmaterial.

Menurut Sedarmayanti ( 2003 : 147 ) kinerja (performance) adalah hasil kerja yang dapat dicapai oleh seseorang atau kelompok orang dalam suatu organisasi sesuai dengan wewenang masing-masing dalam upaya pencapaian tujuan organisasi secara legal, tidak melanggar hukum, sesuai dengan moral dan etika.

Pengertian kinerja dalam penelitian ini adalah suatuhasil kerja yang dicapai oleh masing-masing pegawai yang dalampelaksanaan tugas pekerjaan berdasarkan ukuran dan waktu yang telahditentukan guna mewujudkan tujuan organisasi.

\section{Indikator Kinerja}

Perlu adanya indikator kinerja yang digunakan untuk meyakinkan bahwakinerja hari demi hari menunjukkan kemajuan dalam rangka mewujudkantercapainya sasaran maupun tujuan organisasi yang bersangkutan.Kumorotomo (1996) menggunakan beberapa kriteria untuk dijadikan pedoman dalam menilai kinerja organisasi pelayanan publik, antara lain adalah :

1. Efisiensi.

2. Efektivitas.

3. Keadilan.

4. Daya Tanggap.

Menurut Dwiyanto (1995) terdapatlima indikator yang digunakan untuk mengukur kinerja organisasi publik, yaitu sebagai berikut:

1. Produktivitas.

2. Kualitas Layanan

3. Responsivitas.

4. Resposibilitas.

5. Akuntabilitas

Kriteria organisasi tersebut secara keseluruhan harus dapat dipertanggungjawabkan secara transparan demi memenuhi kriteria daya tanggap ini.

Indikator kinerja menurut LAN - RI

(1999:7) adalah :

1. Indikator kinerja input.

2. Indikator kinerja output.

3. Indikator kinerja outcome.

4. Indikator kinerja manfaat.

5. Indikator kinerja dampak.

\section{Faktor-faktor yang \\ Mempengaruhi Kinerja}

Menurut A. Dale Timple (dalam Mangkunegara, 2005:15), faktor-faktorkinerja terdiri dari faktor internal dan faktor eksternal. Faktor internal(disposisional) yaitu 
faktor yang dihubungkan dengan sifat-sifat seseorang, misalnya karena mempunyai kemampuantinggi dan tipe pekerja keras. Faktoreksternal yaitu faktor-faktor yang mempengaruhi kinerja seseorang yang berasaldari lingkungan. Seperti perilaku, sikap, dan tindakan-tindakan rekan kerja,bawahan atau pimpinan, fasilitas kerja, dan iklim organisasi.

Amstrong dan Baron (1998 : 7-8) mengemukakan bahwa kinerja pegawai dipengaruhi oleh empat faktor yang dominan, yaitu :

1. Faktor kepemimpinan

2. Faktor pribadi

3. Faktor sistem

4. Faktor situasional

\section{Penilaian Kinerja Pegawai}

Menurut Rivai (2005:309), salah satu cara yang dapat digunakan untuk melihat perkembangan perusahaan atau organisasi adalah dengan cara melihat hasil penilaian kinerja.

Pengertian penilaian kinerja pegawai berdasarkan Peraturan PemerintahRepublik Indonesia Nomor 46 tahun 2011 Tentang Penilaian Prestasi Kerja PegawaiNegeri Sipil, penilaian prestasi kerja PNS adalah suatu proses penilaian secarasistematis yang dilakukan oleh pejabat penilai terhadap sasaran kerja pegawai danperilaku kerja PNS.

\section{Tujuan Penilaian Kinerja Pegawai}

Tujuan penilaian kinerja adalah untuk memperbaiki dan meningkatkan kinerjaorganisasi melalui peningkatan kinerja SDM organisasi, dalam penilaian kinerja tidakhanya semata-mata menilai hasil fisik tetapi pelaksanaan pekerjan secarakeseluruhan yang menyangkut berbagai bidang seperti kemampuan, kerajinan,disiplin, hubungan kerja atau hal-hal khusus sesuai dengan bidang dan tugasnyasemuanya layak untuk dinilai.

Berdasarkan Peraturan Pemerintah Republik IndonesiaNomor 46 tahun 2011 Penilaian prestasi kerja PNS bertujuan untuk menjaminobjektivitas pembinaan PNS yang dilakukan berdasarkan sistem prestasi kerja dansistem karier yang dititikberatkan pada sistem prestasi kerja.

\section{Manfaat Penilaian Kinerja Aparatur}

Adapun manfaat dari penilaian kinerja adalah sebagaiberikut :

- Untuk memperbaiki pelaksanaan pekerjaan yang keliru oleh para pegawai,dan sebagai masukan bagi para pimpinan dalam membantu danmengarahkan pegawai dalam memperbaiki pelaksanaan pekerjaannya dimasa depan.

- Membantu pengambilan keputusan yang bersangkutan dengan pegawai,seperti : promosi, transfer, dan pemberhentian.

- Mengelola operasi organisasi secara efektif dan efisien melaluipemotivasian pegawai secara maksimum.

- Berguna untuk melaksanakan perbaikan dan penyempurnaan kegiatanmanajemen SDM lainnya.

\section{Penilaian Kinerja Berdasarkan PP Nomor 46 Tahun 2011}

Berdasarkan Peraturan Pemerintah Republik Indonesia Nomor 46 tahun 2011, Penilaian prestasi kerja PNS dilakukan berdasarkan prinsip objektif, terukur, akuntabel, partisipatif, transparan.

Penilaian prestasi kerja dilakukan dengan cara menggabungkan penilaian SKP dengan penilaian perilaku kerja. Penilaian SKP memuat kegiatan tugas jabatandan target yang harus dicapai dalam kurun waktu penilaian yang bersifat nyata dandapat diukur. Penilaian SKP membandingkan antara kinerja yang dicapai dan targetyang ditentukan sedangkan penilaian Perilaku Kerja dilakukan melalui pengamatanoleh pejabat penilai terhadap PNS sesuai dengan kriteria yang ditentukan. Tata cara penilaian kinerja pegawai adalah dengan menilai dua unsur tersebut dengan bobot nilai unsur SKP 60\% dan Perilaku Kerja sebesar 40\%.

Nilai prestasi kerja PNS sebagaimanadimaksud dalam Pasal 15 dinyatakan dengan angka dan sebutan sebagai berikut:

- 91 - ke atas: sangat baik

- 76 - 90: baik

- 61 - 75: cukup

- 51 - 60: kurang

- 50 ke bawah: buruk

\section{Sasaran Kerja Pegawai}


Sasaran Kerja Pegawai yang selanjutnya disingkat SKP adalah rencana kerja pegawai yang disusun berdasarkan rencana kerja tahunan instansi dan target yang akan dicapai dari setiap pelaksanaan tugas jabatan oleh seorang PNS. Rencana dan target kerja tersebut disusun setiap awal tahun oleh pegawai, dan harus disetujui oleh atasan lagsung/pejabat penilainya.

$$
\text { Penilaian kinerja dengan }
$$

menggunakan SKP ini meliputi beberapa aspek, yakni :
1. Kuantitas
2. Kualitas
3. Waktu
4. Biaya

Keempat aspek tersebut sesuai dengan karakteristik, sifat dan jenis kegiatan pada masing-masing instansi. Lebih lanjut dijelaskan pula bahwa aspek-aspek tersebut disusun dengan mengacu pada standar teknis kegiatan masing-masing instansi. Adapun penilaian dilakukan dengan membandingkan aspek-aspek penilaian pada target di awal tahun dengan realisasi yang dicapai pada akhir tahun.

\section{Perilaku Pegawai}

Selain dengan SKP, prestasi kerja pegawai juga diukur dengan indikator perilaku kerja. Perilaku Kerja adalah setiap tingkah laku, sikap atau tindakan yang dilakukan oleh PNS atau tidak melakukan sesuatu yang seharusnya dilakukan sesuai dengan ketentuan peraturan perundangundangan. Parameter yang digunakan untuk mengukur perilaku kerja adalah orientasi pelayanan, integritas, komitmen, disiplin, kerjasama, dan khusus bagi pejabat struktural ditambah satu dimensi yaitu kepemimpinan. Definisi operasional dari indikator-indikator tersebut adalah sebagaimana dijelaskan dalam penjelasan pasal demi pasal dalam Peraturan Pemerintah Nomr 46 Tahun 2011.

\section{Orientasi Pelayanan}

Yang dimaksud dengan "Orientasi pelayanan" adalah sikap dan perilakukerja PNS dalam memberikan pelayanan terbaik kepada yang dilayani antaralain meliputi masyarakat, atasan, rekan sekerja, unit kerja terkait, dan/atauinstansi lain.

Kepuasan atau ketidakpuasan adalah kesimpulan dari interaksi antaraharapan dan pengalaman sesudah memakai jasa atau pelayanan yang diberikan.Upaya untuk mewujudkan kepuasan pelanggan total bukanlah hal yang mudah.

\section{Integritas}

Integritas adalah konsistensi dan keteguhan yang taktergoyahkan dalam menjunjung tinggi nilai-nilai luhur dan keyakinan definisilain dari integritas adalah suatu konsep yang menunjuk konsistensi antaratindakan dengan nilai dan prinsip. Dalam etika, integritas diartikan sebagaikejujuran dan kebenaran dari tindakan seseorang.

\section{Komitmen}

"Komitmen" merupakan kemauan dan kemampuan untukmenyelaraskan sikap dan tindakan PNS untuk mewujudkan tujuan organisasidengan mengutamakan kepentingan dinas daripada kepentingan diri sendiri,seseorang, dan/atau golongan.

Di dalam Peraturan BKN Nomor 1 Tahun 2013, komitmen diukur dengan sungguh-sungguh menegakkan ideologi negara pancasila, UUD 1945, Negara Kesatuan Republik Indonesia (NKRI), dan rencana-rencana pemerintah dengan tujuan untuk dapat melaksanakan tugasnya secara berdaya guna dan berhasil guna serta mengutamakan kepentingan kedinasan daripada kepentingan pribadi dan/atau golongan sesuai dengan tugas, fungsi, dan tanggungjawabnya sebagai unsur aparatur negara terhadap organisasi tempat dimana ia bekerja.

\section{Disiplin}

"Disiplin" adalah kesanggupan Pegawai Negeri Sipil untuk menaatikewajiban dan menghindari larangan yang ditentukan dalam peraturanperundang-undangan dan/atau peraturan kedinasan yang apabila tidakditaati atau dilanggar dijatuhi hukuman disiplin.

Di dalam pengimplementasian kedisiplinan, berdasarkan Peraturan BKN Nomor 1 Tahun 2013 diukur dengan selalu mentaati peraturan perundang-undangan dan/atau peraturan kedinasan yang berlaku dengan rasa tanggung jawab dan selalu mentaati ketentuan jam kerja serta mampu menyimpan dan/atau memelihara barang- 
barang milik negara yang dipercayakan kepadanya dengan sebaik-baiknya.

\section{Kerjasama}

Kerja sama adalah sebuah sistem pekerjaan yang kerjakan oleh duaorang atau lebih untuk mendapatkan tujuan yang direncanakan bersama.

Pengukuran kerjasama menurut Peraturan BKN Nomor 1 Tahun 2013 adalah dengan selalu mampu bekerjasama dengan rekan kerja, atasan, bawahan baik di dalam maupun di luar organisasi serta menghargai dan menerima pendapat orang lain, bersedia menerima keputusan yang diambil secara sah yang telah menjadi keputusan bersama.

\section{Kepemimpinan}

Kepemimpinan atau leadership merupakan ilmu terapan dari ilmu-ilmusosial, sebab prinsip-prinsip dan rumusannya diharapkan dapatmendatangkan manfaat bagi kesejahteraan manusia (Moejiono, 2002).

Ada beberapa tipe kepemimpinan yang diutarakan oleh Sutikno (2014 : 35), yaitu :

1. Tipe Otokratik

2. Tipe Kendali Bebas (Laisez Faire)

3. Tipe Paternalistik

4. Tipe Kharismatik

5. Tipe Militeristik

6. Tipe Pseudo-demokratik

7. Tipe Demokratik

\section{Aparatur Sipil Negara}

\section{Pengertian Aparatur Sipil Negara}

Dalam Undang-undang No 5 Tahun

2014 tentang Aparatur Sipil Negara, pada pasal 1 dijelaskan bahwa Aparatur Sipil Negara, yang selanjutnya disebut ASN adalah profesi bagi Pegawai Negeri Sipil (PNS) dan Pegawai Pemerintah dengan Perjanjian Kerja (PPPK) yang bekerja pada instansi pemerintah.Dengan demikian, pegawai ASN terdiri dari PNS dan PPPK.

\section{Fungsi, Tugas dan Peran ASN}

Di dalampasal 10 Undang-Undang No 5 Tahun 2014 dijelaskan bahwa Pegawai ASN berfungsi sebagai pelaksana kebijakan publik, pelayan publik, serta perekat dan pemersatu bangsa.

Adapun tugas dari ASN adalah

1. Melaksanakan kebijakan publik yang dibuat oleh Pejabat Pembina
Kepegawaian sesuai dengan ketentuan peraturan perundang-undangan;

2. Memberikan pelayanan publik yang profesional dan bekualitas, dan

3. Mempererat persatuan dan kesatuan Negara Kesatuan Republik Indonesia.

Pegawai ASN berperan sebagai perencana, pelaksana, dan pengawas penyelenggaraan tugas umum pemerintahan dan pembangunan nasional melalui pelaksanaan kebijakan dan pelayanan publik yang profesional, bebas dari intervensi politik, serta bersih dari praktik korupsi, kolusi, dan nepotisme.

\section{Jabatan Aparatur Sipil Negara}

Pada pasal 13 UU ASN disebutkan bahwa jabatan ASN terdiri dari Jabatan Administrasi, Jabatan Fungsional, dan Jabatan Pimpinan Tinggi.

\section{Metode Penelitian}

Jenis Penelitian

Metode penelitian kualitatif ini digunan untuk memperoleh pemahaman tentang kinerja Aparatur Sipil Negara di Dinas Kearsipan dan Perpustakaan Kota Kediri, dengan faktor pendukung dan penghambatnya sesuai dengan butir-butir rumusan masalah, tujuan dan manfaat penelitian.

\section{Lokasi Penelitian}

Penelitian yang penulis teliti mengenai evaluasi kinerja ASN ini dilakukan di Dinas Kearsipan dan Perpustakaan Kota Kediri.

\section{Sumber Data/Informan}

Sumber data dalam penelitian ini adalah pegawai Dinas Kearsipan dan Perpustakaan Kota Kediri sebanyak 22 (dua puluh dua) orang. Untuk menentukan jumlah sumber data dalam penelitian ini penulis menggunakan populasi.

\section{Teknik Pengumpulan Data}

Teknik pengumpulan data yang digunakan dalam penelitian ini adalah:

1. Wawancara

2. Observasi

3. Dokumentasi

\section{Teknik Analisis Data}


Dalam menganalisa data, peneliti menggunakan model Miles and Huberman :

1. Reduksi Data (Data Reduction)

2. Penyajian Data (Data Display)

3. Penarikan kesimpulan (Conclusion Drawing / verification)

Hasil Penelitian dan Pembahasan Sejarah Dinas Kearsipan dan Perpustakaan Kota Kediri

Dinas Kearsipan dan Perpustakaan Kota Kediri dibentuk berdasarkan Undang Undang Nomor 7 Tahun 1971 tentang Ketentuan - Ketentuan Pokok Kearsipan (Lembaran Negara Republik Indonesia Tahun 1971 Nomor 32, Tambahan Lembaran Negara Republik Indonesia Nomor 2964) dan Undang-Undang Nomor 43 Tahun 2007 tentang Perpustakaan (Lembaran Negara Republik Indonesia Tahun 2007 Nomor 129, Tambahan

\section{Lokasi}

\begin{tabular}{lrr}
\multicolumn{2}{c}{ LokasiDinas } & Kearsipan dan \\
Perpustakaan & Kota & Kediriberadadi \\
Jln.Diponegoro 9 Kediri &
\end{tabular}

Visi dan Misi

VisiDinas Kearsipan dan

Perpustakaan Kota Kediriadalah:

"Terdepan dalam Mewujudkan Masyarakat Kota Kediri Yang Cerdas, Berwawasan luas, dan Berkwalitas Tahun 2017”

Untukmewujudkanvisi yang telahditetapkanmakaDinas Kearsipan dan Perpustakaan Kota Kediri mempunyaimisi:

1) Mengembangkan sarana, prasarana, dan koleksi perpustakaan, serta teknologi pengelolaan perpustakaan.

2) Membina dan mengembangkan semua jenis perpustakaan yang ada di daerah

3) Memotivasi dan membina minat dan budaya baca masyarakat.

4) Meningkatkan dan mengembangkan sistem dan teknologi penataan dan pengelolaan kearsipan, sehingga dapat dicapai tertib administrasi yang baik dan benar.
Lembaran Negara Republik Indonesia Nomor 4774,Dinas Kearsipan dan Perpustakaan Kota Kediri pada mulanya merupakan Kantor Kearsipan, Perpustakaan dan Dokumentasi. Struktur organsiasi tersebut berlangsung hingga pada tahun 2016 yang kemudian berubah menjadi Dinas Kearsipan dan Perpustakaan Kota Kediri berdasarkan Peraturan Daerah Kota Kediri Nomor 7 Tahun 2016 tentang Pembentukan dan Susunan Perangkat Daerah Kota Kediri (Lembaran Daerah Kota Kediri Tahun 2016 Nomor 9, Tambahan Lembaran Daerah Kota Kediri Nomor 43)..

Struktur organisasi Dinas Kearsipan dan Perpustakaan Kota Kediri mulai dari awal pembentukan hingga saat ini telah mengalami dua kali perubahan. Struktur yang terakhir adalah sesuai dengan yang ditetapkan melalui Peraturan Walikota KediriNomor 55Tahun 2016

\section{Kinerja ASN pada Dinas Kearsipan dan Perpustakaan Kota Kediri Orientasi pelayanan \\ Rata-rata orientasi pelayanan} ASN di Dinas Kearsipan dan Perpustaan Kota Kediri dalam kategori baik dengan skor 80. Hal ini karena tidak semua ASN di Dinas Kearsipan dan Perpustaan Kota Kediri melaksanakan pelayanan bagi masyarakat, atasan, rekan sekerja, unit kerja terkait, dan/atau instansi lain. Beberapa yang mendapat skor tertinggi dari kategori baik karena pelayanan yang dilaksanakan sudah meliputi 5 obyek.

Bidang Perpustakaan melayani masyarakat, rekan sekerja, unit kerja lain di Pemerintah Kota Kediri antara lain PKK Kelurahan, instansi terkait dengan sekolah (PAUD, TK, SD dan SMO), BI, Kepolisian, Samsat dan instansi lainnya

Bidang Kearsipan juga melakukan pelayanan kepada masyarakat, rekan sekerja, unit kerja lain di Pemerintah Kota Kediri, lembaga masyarakat dan lembaga pendidikan.

\section{Integritas}

Integritas ASN Dinas Kearsipan dan Perpustakaan Kota Kediri pada kategori baik, walaupun mendapat predikat instansi "TPA" tidak membuat semua ASN di Dinas Kearsipan dan Perpustakaan Kota Kediri menurun integritasnya. 


\section{Komitmen}

Indikator komitmen yang diambila adalah melaksanakan tugas secara efektif dan efisien serta mengutamakan kepentingan kedinasan daripada kepentingan pribadi dan golonganASN Dinas Kearsipan dan Perpustakaan terlihat pada jadwal dan jangkauan pelayanan Bidang Perpustakaan tidak hanya pada jam dinas, tempat layanan perpustakaan keliling yang menjangkau taman-taman, sekolah, rusunawa dan peminjaman buku-buku di instansi lain di luar Pemerintah Kota Kediri.

Komitmen Bidang Kearsipan terhadap kepentingan dinas patut juga diapresiasi. Di tengah penilaian buruk hasil monitoring dan evaluasi Pengawasan Kearsipan oleh Dinas Perpustakaan dan Kearsipan Provinsi Jawa Timur karena dua indikator utama tidak dimiliki Dinas Kearsipan dan Perpustakaan Kota Kediri yaitu Depo Arsip dan Arsiparis namun kegiatan pembinaan kearsipan bagi instansi Pemerintah Kota Kediri, pembinaan kearsipan bagi Sekolah, UPTD kesehatan dan Mahasiswa telah dilaksanakan. Juga lomba tata kearsipan bagi Kelurahan se-Kota Kediri yang diselenggarakan Tahun 2017 belum banyak instansi kearsipan di Jawa Timur yang menyelenggarakan.

\section{Disiplin}

Di Dinas Kearsipan dan Perpustakaan Kota Kediri tingkat kedisiplinan ASN masih kurang baik. Banyak yang tidak mengikuti apel pagi sore, tidak mentaati ketentuan jam kerja dan kurang mampu menyimpan dan/atau memelihara barang-barang milik negara yang dipercayakan kepadanya dengan sebaikbaiknya sebagai indikator disiplin ASN.

Namun dari indikator kemauan dalam mentaati peraturan perundangundangan dan/atau peraturan kedinasan yang berlaku dengan rasa tanggung jawab ASN Dinas Kearsipan dan Perpustakaan Kota Kediri cukup baik.

\section{Kerjasama}

Kerjasama sesama rekan kerja ASNDinas Kearsipan dan Perpustakaan Kota Kediri belum optimal, hal ini terlihat dari kegiatan masing-masing bidang yang berjalan sendiri-sendiri, beberapa tugas-tugas rutin pemerintahan terkadang lambat direspon bidang karena koordinasi yang lemah.

\section{Kepemimpinan}

Kepemimpinan di Dinas Kearsipan dan Perpustakaan Kota Kediri pada umumnya sudah memiliki ketegasan, ada yang belum memberikan teladan yang baik, kemampuan menggerakkan tim kerja belum optimal dan kemampuan mengambil keputusan dengan cepat dan tepat belum optimal berdasarkan hasil observasi dan wawancara ASN.

\section{Realisasi Penilaian Prestasi Kerja menggunakan SKP}

Apa yang tertulis di SKP masih ada yang tidak sesuai dengan kondisi yang sebenarnya. Sebagai contoh, ketika peneliti melihat kondisi di lapangan, ada beberapa ASN yang memiliki kedisiplinan kurang bagus. Dia sering tidak ikut apel. Saat kembali dari istirahat pun melebihi jam istirahat. Namun di dokumen SKP, ASN tersebut dalam hal kedisiplinan masih tetap mendapatkan nilai 80 . Hal ini tentu saja tidak sesuai dengan kenyataan yang ada.

Contoh lain dari segi kerja sama. Ketika ada salah seorang ASN yang susah diajak kerjasama, di dokumen SKP menunjukkan bahwa nilai kerjasama yang dia dapatkan masih diatas nilai 76 .

Pimpinan tidak menilai dengan sangat detail. Hanya melihat aspek perilaku dari keseharian pegawai secara sekilas. Selama pegawai tidak melakukan pelanggaran yang berat, pejabat penilai akan memberikan nilai baik. Pejabat penilai hanya melihat pada Penilaian Prestasi Kerja, sedangkan pada form Penilaian Sasaran Kerja Pegawai, pejabat penilai hanya asal tanda tangan saja karena untuk mengingat-ingat kegiatan selama 12 bulan akan sangat sulit.

Perlu dilakukan pengkajian ulang terhadap penilaian ASN dengan menggunakan SKP. Nilai subyektivitas pimpinan masih sulit untuk dihilangkan dalam penilaian tersebut. Biasanya pimpinan sebagai pejabat penilai, hanya berpatokan pada uraian pekerjaan yang tertulis di SKP sudah sesuai atau belum dengan tupoksinya. Jika sudah sesuai dengan tupoksi yang ada, 
biasanya diberikan nilai yang baik. Sedangkan untuk aspek perilaku kerja, pimpinan biasanya melihat keseharian bawahan dalam berinteraksi dengan dirinya maupun rekan kerja yang lain.

Faktor Pendukung dan Penghambat Kinerja ASN

\section{Faktor Pendukung}

a. Adanya semangat/motivasi diri yang kuat untuk melaksanakan pekerjaan dengan penuh tanggung jawab, berintegritas dan penuh komitmen.

b. Adanya reward TPP dari Pemerintah Kota Kediri sangat berpengaruh pada peningkatan kinerja ASN Dinas Kearsipan dan Perpustakaan Kota Kediri

c. Lingkungan kerja yang kondusif yang perlu dipertahankan terutama oleh pimpinan agar kinerja ASN lebih meningkat

\section{Faktor Penghambat}

a. Kurangnya Sumber Daya Manusia (SDM).

Kendala dalam kinerja pegawai dalam melaksanakan pekerjaan yaitu masih terbatasnya jumlah tenaga Sumber Daya Manusia (SDM) yang ada di Dinas Kearsipan dan Perpustakaan Kota Kediri. Kurangnya Sumber Daya Manusia (SDM) menyebabkan pekerjaan membutuhkan waktu yang lama karena ketidakseimbangan antara yang dilayani dengan yang melayani. Banyaknya pekerjaan yang harus ditangani dalam satu waktu dengan jumlah tenaga kerja yang sedikit menyebabkan petugas merasa terbebani dengan tupoksinya. Untuk bisa menyelesaikan pekerjaan tepat waktu, harus memerlukan tambahan waktu diluar jam kerja.

Jumlah SDM Fungsional Pustakawan jumlahnya belum memenuhi standar dan tidak adanya SDM Fungsional Arsiparis merupakan kendala terberat dalam peningkatan kinerja ASN Dinas Kearsipan dan Perpustakaan. Namun dengan semangat dan motivasi belajar yang tinggi dari ASN yang ada tupoksi tetap berjalan sesuai rencana.

b. Kurangnya Sarana dan Prasarana.

Berdasarkan hasil pengamatan peneliti, kurang tersedianya sarana dan prasarana yang cukup memadai. Sarana dan prasarana merupakan faktor penunjang yang sangat penting dalam meningkatkan kinerja pegawai karena berpengaruh langsung terhadap semangat pegawai dalam menyelesaikan pekerjaannya. Dengan tersedianya fasilitas yang cukup, maka pekerjaan menjadi lebih ringan serta hemat waktu dan tenaga untuk dikerjakan sehingga hasil yang didapatkan pun menjadi lebih maksimal sehingga tujuan yang hendak dicapai dapat dengan mudah diwujudkan.

Dinas Kearsipan dan Perpustakaan Kota Kediri juga tidak memiliki beberapa ruang vital antara lain :

$\checkmark$ Depo Arsip, sejak depo arsip Dinas Kearsipan dan Perpustakaan Kota Kediri roboh terkena letusan Gunung Kelud sampai sekarang belum ada perbaikan atau pembangunan kembali

$\checkmark$ Sarana Penyimpanan Arsip masih sangat terbatas

$\checkmark$ Gedung Perpustakaan Umum yang masih memakai Gedung Mastrip

c. Kurangnya alokasi anggaran baik untuk dinas sendiri maupun anggaran untuk meningkatkan kompetensi pegawai.

Keinginan yang kuat dari ASN dalam hal pengembangan diri, potensi dan kompetensi tidak diiringi dengan adanya alokasi yang mencukupi dalam menunjang kinerja ASN. Tentu saja hal itu sangat disayangkan melihat semangat untuk mengembangkan diri dari ASN.

\section{Penutup \\ Simpulan}

Kinerja Aparatur Sipil Negara (ASN) pada Dinas Kearsipan dan Perpustakaan Kota Kediri secara umum sudah cukup bagus. Hal itu terlihat dari beberapa indikator sebagai berikut :

a. Pelayanan di Dinas Kearsipan dan Perpustakaan Kota Kediri bagus. Petugasnya ramah, sopan, cepat, dan memberikan penjelasan dengan baik. Kurangnya alokasi anggaran untuk menyelenggarakan maupun memfasilitasi diklat juga menjadi penghambat bagi ASN dalam meningkatkan pelayanan mereka. 
b. ASN di Dinas Kearsipan dan Perpustakaan Kota Kediri memiliki integritas yang bagus.

c. Komitmen yang dimiliki oleh Dinas Kearsipan dan Perpustakaan Kota Kediri bagus. Dengan keterbatasan SDM, sarana dan prasarana tidak menjadi penghambat dalam memberikan pelayanan terbaik.

d. Kedisiplinan ASN di Dinas Kearsipan dan Perpustakaan Kota Kediri masih kurang. Masih banyak yang datang hanya finger print saja.

e. Kerjasama masih perlu ditingkatkan agar pencapaian kinerja lebih meningkat.

f. Kepemimpinan di Dinas Kearsipan dan Perpustakaan Kota Kediri ditingkatkan. Ketegasan, kemampuan memberikan teladan, kemampuan menggugah semangat dan menggerakkan bawahan masih perlu dioptimalkan

\section{Saran}

1. Perhatian dari pimpinan kepada bawahan diperlukan untuk memberikan semangat kerja kepada mereka. Motivasi diri yang kuat dari ASN untuk memberikan kinerja terbaik bagi Dinas Perpustakaan dan Kearsipan Kota Kediri harus terus dipupuk dan diapresiasi agar bertambah optimal

2. Komunikasi yang terbuka dan melakukan aktifitas diluar bersama-sama diperlukan agar suasana antar bidang dan sesama ASN bisa lebih cair.

3. Perlunya penambahan jumlah pegawai baik dari jabatan fungsional umum maupun jabatan fungsional pustakawan dan arsiparis.

\section{Daftar Pustaka}

Armstrong. Michael and Baron, 1998. Performance Manajemen, (Alih Bahasa: Tony Setiarvan), Yogyakarta: Tugu Publisher

Dwiyanto, Agus 1995. Penilaian Kinerja Organisasi Pelayanan Publik. Yogyakarta : Fisipol UGM

Imam,Moejiono, 2002, "Kepemimpinan dan Keorganisasian”, Yogjakarta, UII Press.

Mangkunegara. A.A Anwar Prabu. 2005 .Evaluasi Kinerja Sumber Daya Manusia. Bandung: Refika Aditama.
Rivai, Veithzal. 2005. Manajemen Sumber Daya Manusia Untuk Perusahaan. Jakarta : PT. Raja Grafindo Persada.

Sedarmayanti, 2001. Manajemen Sumber Daya Manusia, Bandung, Mandar Maju.

Simamora, Henry, 1999. Manajemen Sumber Daya Manusia, STIE YKPN, Jakarta

Sutikno. (2014). Pemimpin dan Kepemimpin: Tips Praktis untuk Menjadi Pemimpin yang diidolakan. Lombok; Holistica Lombok

\section{Peraturan dan Perundang-undangan :}

Undang-Undang Nomor 5 Tahun 2014 Tentang Aparatur Sipil Negara.Sekretariat Negara. Jakarta.

Undang-Undang Nomor 7 Tahun 1971 Tentang Ketentuan - ketentuan Pokok Kearsipan

Undang-Undang Nomor 43 Tahun 2007 Tentang Perpustakaan

Peraturan Pemerintah Nomor 46 Tahun 2011 Tentang Penilaian Prestasi Kerja Pegawai Negeri Sipil

Peraturan Pemerintah Nomor 18 Tahun 2016 tentang Perangkat Daerah. Sekretariat Negara. Jakarta.

Peraturan Kepala BKN RI No 1 Tahun 2013. Badan Kepegawaian Negara. Jakarta.

Peraturan Daerah Kota Kediri Nomor 7 Tahun 2016 tentang Pembentukan dan Susunan Perangkat Daerah Kota Kediri

Peraturan Walikota Nomor 55 Tahun 2016 Kedudukan, Susunan Organisasi, Tugas Dan Fungsi Serta Tata Kerja Dinas Kearsipan Dan Perpustakaan. 